\title{
The Effect of Curcuma Zedoaria (Berg.) Roscoe Extract on Liver Function Tests of Rattus norvergicus Exposure by Cigarette Smoke
}

\author{
Sudir Sumarheni ${ }^{1}$, Nursyamsi ${ }^{2}$, Rina Agustina ${ }^{3}$, Fitriyani ${ }^{4}$, Fauziah Amin ${ }^{5}$, \\ Rahmawati Faisal $^{6}$, Sartini ${ }^{7}$ \\ \{ sumarheni@unhas.ac.id ${ }^{1}$,nursyamsi0207@gmail.com ${ }^{2}$,rina_agustina84@yahoo.co.id ${ }^{3}$, \} \\ Faculty of Pharmacy, Hasanuddin University, Makassar, Indonesia ${ }^{1,3-7}$ \\ Faculty of Medicine, Hasanuddin University, Makassar Indonesia ${ }^{2}$
}

\begin{abstract}
Curcuma zedoaria (Berg.) Roscoe has been widely used traditionally as a valuable medicinal plant to treat many diseases due to its activity on repairing cell damage. This study aimed to evaluate the effect of ethanol extract of Curcuma zedoaria (CZE) on liver function test levels in male Winstar rats exposed by cigarette smoke. A total of 30 male rats were divided into six groups $(\mathrm{n}=5)$, i.e., control group $(\mathrm{G} 1)$; negative control(G2); positive control(G3); cigarette smoke-exposure followed by administration of CZE $350 \mathrm{mg} / \mathrm{kg}$ b.wt group $(\mathrm{G} 4)$, cigarette smoke-exposure followed by administration of CZE $525 \mathrm{mg} / \mathrm{kg}$ b.wt group(G5), and administration of CZE $525 \mathrm{mg} / \mathrm{kg}$ b.wt group (G6). Treatments were given for 45 days before blood collection and MDA measurements on rat liver tissue. The results showed that administration of $350 \mathrm{mg} / \mathrm{kg}$ b.wt., and $525 \mathrm{mg} / \mathrm{kg}$ b.wt reduced total protein, ALT, AST and ALP levels on rat exposed by cigarette smoke as well as decreased liver peroxidase level based on the average profile of MDA on rat liver tissue. In conclusion, administration of CZE showed the hepatoprotective effect on rats exposed by cigarette smoke.
\end{abstract}

Keywords: Curcuma zedoaria, cigarette

\section{Introduction}

Smoking is one of the most severe health-behavior problems considered as the causes of death in the world. The number of smokers' worldwide increase tremendously from about 5.8 billion in 2014 to more than 1.1 trillion in 2018. More than 6 million deaths in the world related to cigarette consumption, whereas about 890,000 of those are the result of exposure to secondhand smoke [1]. In Indonesia, there are approximately 50.6 million adults (aged 15 years and over) become active smokers [1], [2]. Riskesdas (2013) had identified that at least 25,000 passive smoker deaths are due to smoke exposure from active smokers near them.

Cigarette smoke has been known to contain many toxic components including various oxidants such as oxygen-free radicals or reactive oxygen species (ROS) and volatile aldehydes that allow damage into biomolecules [3], [4]. Activities of the free radical leading to oxidative stress have the potential risks to initiate or promote oxidative damage in the cellular level including damage to membrane lipids that make up cells, proteins, carbohydrates, and DNA [5]. It has been reported that oxidative damage caused by free radicals has implications for 
various pathological conditions to tissues and vital organs such as the liver, kidneys, heart in both humans and animals [6].

A potential risk factor of liver cancer by increasing the risk of cirrhosis and affect the development of chronic liver disease could be triggered by prolonged ROS accumulation led by toxic chemical exposure [7]. Several studies showed that therapeutically use of components that counteract ROS activity was based on its progressive prevention on the pre-cancer stage [8], [9]. Nevertheless, either toxicants or drugs, including anticancer substances are known to have a substantial first-pass hepatic metabolism which potentially caused more damage to the liver [9], [10], [11]. Therefore, the development of natural compounds that have anticancer activity is expected to reduce the risk of liver damage compared to synthetic chemicals [12].

White Turmeric or Curcuma zedoaria (Zingiberaceae) had been used traditionally to treat many diseases, and the ethanol extract (CZE) has a hepatoprotective effect as well as high potency against cancer cell with less activity in the normal cell. Some studies suspected that the anticarcinogenic effect of CZE was due to its antioxidant activity [13], [14], [15]. Moreover, a cytotoxic test of CZE showed that the extract has $\mathrm{IC}_{50}$ of $6.05,17.84$ and 55.50 $\mu \mathrm{g} / \mathrm{ml}$ respectively to the lung cancer cell, prostate cancer and normal cells with an $\mathrm{LD}_{50}$ value of $1000 \mathrm{mg} / \mathrm{kg} \mathrm{BW}$ [16]. Although evaluation of the potential effect of CZE had widely studied, its hepatoprotective effect against secondhand smoke exposure in Rattus norvegicus model has not been reported. Therefore, the primary objective of this study was to observe the effect of CZE on reducing the effects of free radicals exposed from secondhand cigarette smoke through the parameters of liver function test in blood and liver organ.

\section{Experimental}

\subsection{Preparation of Curcuma zedoaria Ethanol Extract (CZE)}

The rhizomes of $C$. zedoaria were harvested from Sidrap district, South Sulawesi and determined at Laboratory of Biology, Mathematics, and Natural Sciences Faculty, Makassar State University. Preparation of CZE was based on the procedure explained elsewhere [17]. Shortly, the process started by a- 24 hrs vacuum drying process at $45^{\circ} \mathrm{C}$ of clean-cut pieces of C. zedoaria rhizomes. The dried simplicia then achieved with mesh 18 and stored at the airtight container. A three-days conventional maceration process was used to extract the pulverized rhizomes with ethanol $70 \%$ as the solvent $(1: 10)$. The crude liquid of CZE was separated by filtration, and maceration was repeated twice. Evaporation of the solvent of CZE used rotary evaporator $\left(\right.$ Heidolph $^{\circledR}$ ) followed by storage in a desiccator containing dry silica gel to obtain the viscous extract.

\subsection{Animals}

Before the treatments, the male rats (Rattus norvergicus) age 8-10 weeks were acclimatized to environmental and experimental conditions for seven days. The rats were housed in controlled room temperature at $25 \pm 2^{\circ} \mathrm{C}$ under a light/dark cycle of $12 \mathrm{~h}$ in a cage with access to food and water ad libitum. The blood samples were withdrawn via a lateral vein to identify healthy animals, and a total of 30 male rats with an average weight of $150-250 \mathrm{~g}$ were divided into six groups $(n=5)$. 


\subsection{Experimental protocols}

Experimental protocols on the animal use of these studies were approved by the Ethics Commission of Medical Faculty, Hasanuddin University (No. 292/H4.8.4.5.31/PP36KOMETIK/ 2018). These studies were conducted in a posttest-only randomized experimental design that compared six groups of male Wistar rats (Rattus norvergicus). As the antioxidant activity against cancer cell proliferation of C.zedoaria determined in earlier studies, the dose is chosen accordingly with slight modification for dose conversion between animals [18]. The smoking chamber (a glass box size $50 \times 60 \times 40 \mathrm{~cm}$ ) used in this study equipped with a vacuum pump for cigarette smoke and air supply. After the adaptation period of the animals, the treatments were as follow: Group I (G1): normal control rats received 1\% w/v NaCMC (5 $\mathrm{ml} / \mathrm{kg}$ b.wt); Group II(G2): Negative control rats exposed by the smoke of 10 cigarettes (contain $39 \mathrm{mg}$ tar and $2.5 \mathrm{mg}$ nicotine) in the smoking chamber for 30 min every day up to 45 days; Group III: Positive control rats, received cigarette smoke exposure as (G2) and $30 \mathrm{~min}$ further cotreated with Vit. C $10 \mathrm{mg} / \mathrm{kg}$ b.wt by oral gavages for 45 consecutive days; Group IV(G4): Rats treated as (G3) but Vit C replaced by administration of $350 \mathrm{mg} / \mathrm{kg}$ b.wt of CZE in $1 \%$ w/v NaCMC; Group V (G5): Rats treated as (G4) using CZE $525 \mathrm{mg} / \mathrm{kg}$ b.wt; Group VI (G6): Rats received CZE ( $525 \mathrm{mg} / \mathrm{kg}$ b.wt) alone. Rats were weighed every day to adjust the amount of CZE suspension administered. Blood samples were collected 24 hrs following the last treatm ents via a lateral vein then the rats were euthanized to harvest the liver for MDA assay.

\subsection{Blood Biomarkers of Liver Function Tests}

Blood samples were centrifuged $\left(\operatorname{Hettich}^{\circledR}\right.$ ) at $1500 \mathrm{~g} / \mathrm{min}$ for $10 \mathrm{~min}$ to obtain serum. Clinical biochemistry parameters particularly the liver marker enzymes: aspartate aminotransferase (AST), alanine aminotransferase (ALT), alkaline phosphatase (ALP), and total protein were determined using $\mathrm{ABX}$ Pentra 400 diagnostic reagents and instrument $\left(\mathrm{Horiba}^{\circledR}\right)$.

\subsection{Liver MDA Level Analysis}

The concentration of lipid peroxide in liver tissues was measured by thiobarbituric acid (TBA) reaction, which measured the presence of malondialdehyde (MDA) as its product [19]. Individual rat livers were crushed and homogenized before weighed $400 \mathrm{mg}$ using an analytical scale (Sartorius $\left.{ }^{\circledR}\right)$. Two $\mathrm{mL}$ PBS pH 7.4 was added, and the mixture was centrifuged at $3000 \mathrm{rpm}$ for 10 minutes. The supernatant was taken $0.5 \mathrm{ml}$ then added with 1 $\mathrm{ml}$ of TCA $(10 \% \mathrm{~b} / \mathrm{v})$ and $1 \mathrm{ml} \mathrm{TBA}(1 \% \mathrm{~b} / \mathrm{v})$ in a centrifuge tube. The mixture was heated at $90-100^{\circ} \mathrm{C}$ for 40 minutes, cooled to room temperature; then centrifuged again at $3000 \mathrm{rpm}$ for 10 minutes. The absorbance was measured using a UV-Vis spectrophotometer (Shimadzu MR 2500®) at a wavelength of $532 \mathrm{~nm}$ [20].

\subsection{Statistical Analysis}

Data obtained were statistically analyzed using SPSS 20 software with KolmogorovSmirnov method. Normally distributed data, were analyzed by one-way analysis of variance 
ANOVA measurement method then proceed with post hoc test using the LSD test of significance. $\mathrm{P}<0.05$ were considered as significantly different.

\subsection{Results and Discussion}

The characteristics of ethanol extract of $C$. zedoaria obtained after concentrated and stored in a desiccator was similar, as described in Farmakope Herbal Indonesia [17]. The yield of CZE was $27.461 \%$, which showed a thick, viscous brownish extract with a bitter taste and characteristic odor of C.zedoaria.

Table 1. Body weight of rats after 45 days of treatments.

\begin{tabular}{lc}
\hline \multicolumn{1}{c}{ Treatment Groups } & Mean BW \pm SD \\
$(\mathbf{g})$
\end{tabular}

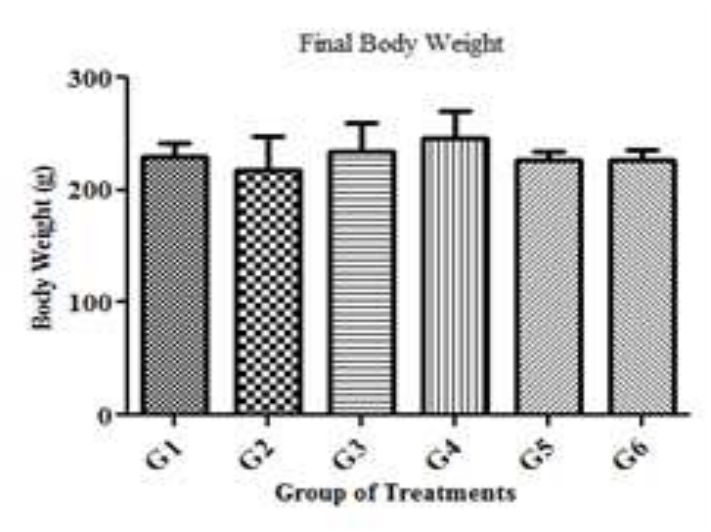

Fig. 1. Effects of treatments on the Body Weight of Rattus norvergicus. Values are mean $\pm S D(n=5)$.

After the adaptation period of the animals, the baseline level of blood biomarkers was measured one day before treatment (day-0). The rats which showed results in the range of rat's reference values as experimental animals [21] were used for this study. Every day, rats were weighed to adjust the number of CZE administered. Data in Table 1 demonstrates the mean body weight of the rats after 45 days of treatments. It is seen that the mean body weight of rats exposed cigarette smoke without other treatments (G2) slightly decreased although still showed no significant differences among other groups (Figure 1). These data were entirely different from other studies which revealed the fast response of weight loss in line with the 
reduction of food consumption and positively associated with increasing doses of nicotine even on short-term cigarette smoke exposure [22], [23]. However, others also concern about the fact that heavy smokers tend to be less active to move physically than non-smokers and potentially gaining more weight as a result [24]. The limitations of this study are the exposure of cigarette smoke that given to rats simultaneously in the smoking chamber causing the amount level of cigarette smoke that inhaled for each rat was unknown, and the habit differences did not observe detailly. However, in general, visual observations, when rats exposed to cigarette smoke, they became restless, which suddenly show slower movements afterward. These observations were by habitual evaluation studies of rodents, which showed anxiety and fatigue after exposure to cigarette smoke [25].

Table 2. The level of blood biomarkers for Rat's Liver Function Tests after 45 days of treatments

\begin{tabular}{lcccc}
\hline \multicolumn{1}{c}{ Treatment Groups } & \multicolumn{3}{c}{ Mean \pm SD } \\
\cline { 2 - 5 } & $\begin{array}{c}\text { Protein Total } \\
(\mathrm{g} / \mathrm{dl})\end{array}$ & $\begin{array}{c}\text { AST } \\
(\mathrm{U} / \mathrm{L})\end{array}$ & $\begin{array}{c}\text { ALT } \\
(\mathrm{U} / \mathrm{L})\end{array}$ & $\begin{array}{c}\text { ALP } \\
(\mathrm{U} / \mathrm{L})\end{array}$ \\
\hline Normal (G1) & $5.7 \pm 0.2$ & $118.0 \pm 7.5$ & $51 \pm 2.6$ & $70.0 \pm 20.0$ \\
\hline Cigarette smoke (G2) & $5.7 \pm 0.1$ & $146.0 \pm 2.0$ & $66.3 \pm 14.0$ & $104.0 \pm 38.5$ \\
\hline Cigarette smoke+vitamin C (G3) & $5.4 \pm 0.4$ & $115.0 \pm 3.5$ & $58.3 \pm 8.0$ & $98.8 \pm 60.6$ \\
\hline $\begin{array}{l}\text { Cigarette smoke+CZE 350 mg/kg b.wt } \\
\text { (G4) }\end{array}$ & $5.4 \pm 0.3$ & $116.0 \pm 4.3$ & $54.0 \pm 5.3$ & $85.0 \pm 10.0$ \\
\hline $\begin{array}{l}\text { Cigarette smoke+CZE 525 mg/kg b.wt } \\
\text { (G5) }\end{array}$ & $5.4 \pm 0.4$ & $114.3 \pm 10.8$ & $55.0 \pm 2.6$ & $83.8 \pm 38.6$ \\
\hline CZE 525 mg/kg b.wt (G6) & $5.6 \pm 0.1$ & $115.0 \pm 4.6$ & $56.0 \pm 9.5$ & $86.7 \pm 46.2$ \\
\hline
\end{tabular}

After 45 days of treatments, the blood samples were withdrawn to evaluate the rat's liver function based on its biochemical parameters (Table. 2). Evaluation of the level of total protein in smokers tends to be lower than non-smokers. Although the increasing level of oxidative stress due to cigarette-smoke exposure proved to stimulate more proteins production for rebalancing [26], higher oxidation of the albumin also rapidly cleared from the circulation and degraded [27]. In this study, total protein in the blood of cigarette smoke-rat groups and non-cigarette smoke groups showed nearly similar levels (Figure 2A). Nevertheless, these levels were slightly lower than the reference levels $(6.3-8.6 \mathrm{mg} / \mathrm{dl})[21]$, meaning that all the treatments given could affect the level of protein total in rats.

Evaluation on the transaminase enzymes after 45 days of treatments showed that there was a significant increase (about 25\%) in mean AST levels in the negative control group received cigarette-smoke exposure compared to the other groups (Figure 2B). A statistically significant reduction $(\mathrm{p}<0.05)$ in AST level between G2 and G3 which received Vit.C were similarly observed on other study used chemicals to induce oxidative stress in rat's liver [28,29]. Therefore, relatively similar data which showed declining AST levels on the groups treated with CZE $350 \mathrm{mg} / \mathrm{b}$.wt (G4) or $525 \mathrm{mg} / \mathrm{b}$.wt (G5) could be associated with the antioxidant properties of CZE to protect hepatotoxicity effect of cigarette smoke.

Evaluation of liver function using more specific biochemistry parameters ALT and ALP also showed an elevation of about $30 \%$ and $50 \%$ respectively on cigarette-smoke exposure group (G2) compare to the negative control group (G1). However, the statistical analysis evaluates that there were no significant differences in all treated groups, which indicates that induction of liver hepatotoxicity through cigarette-smoke exposure for 45 days was 
inadequate. Alteration of AST level considers as a sensitive marker to detect damage in liver cells, yet this transaminase enzyme also presents in large numbers in heart, kidneys, skeletal muscles, and pancreas. Whereas, ALT is widely found in the liver and its elevation level in blood explicitly associated with the liver cell damage caused by drugs or other toxicants [30]. The results in this study found contrary to another study which discovered a high increase in ALT level of the rats after induced by cigarette smoke for 6 weeks [31].
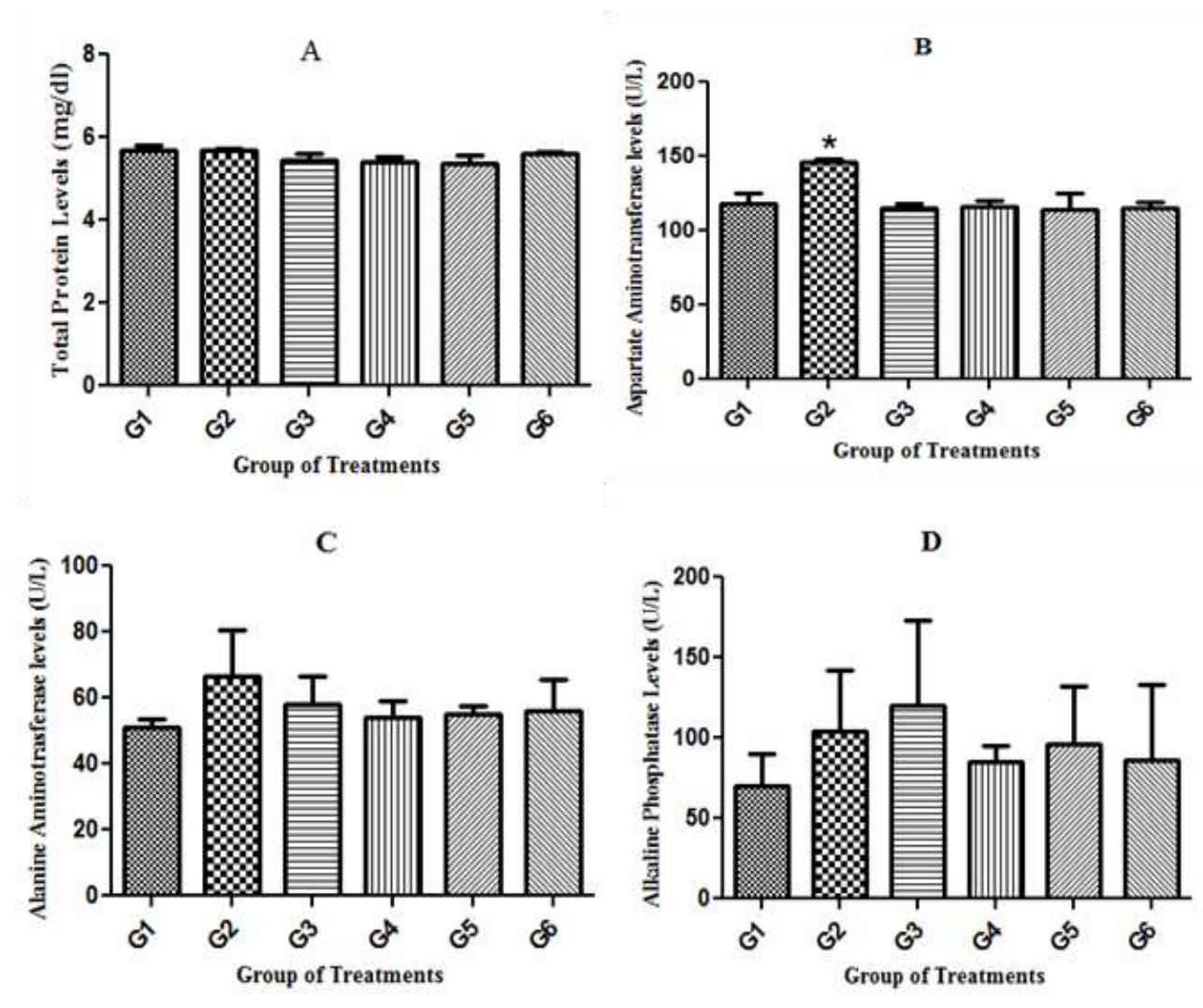

Fig. 1. Effects of ethanol extract of Curcuma zedoaria on the blood biomarkers of Rattus norvergicus exposed by cigarette smoke: total protein levels (A), AST levels (B), ALT levels (C), and ALP levels

(D). Values are mean $\pm \mathrm{SD}(\mathrm{n}=5)$. $\mathrm{G} 1$, control rats; $\mathrm{G} 2$, cigarette-smoke exposed rats; G3, cigarette smoke+Vit. C; G4, cigarette smoke+CZE $350 \mathrm{mg} / \mathrm{kg}$ b.wt; G5, cigarette smoke+CZE $525 \mathrm{mg} / \mathrm{kg}$ b.wt; G6, CZE $525 \mathrm{mg} / \mathrm{kg}$ b.wt. *P<0.05 statistically significant as compared with other groups.

Table 3. Malondialdehyde (MDA) levels on rat's liver after 45 days of treatment

\begin{tabular}{lc}
\hline Treatment Group & Mean \pm SD $(\boldsymbol{\mu g} / \mathbf{m L})$ \\
\hline Normal control (G1) & $0,340 \pm 0,274$ \\
Negative control (G2) & $0,548 \pm 0,197$ \\
Positive control (G3) & $0,293 \pm 0,178$ \\
Cigarette smoke + extract 350 mg/kg b.wt(G4) & $0,296 \pm 0,072$ \\
Cigarette smoke + extract 525 mg/ kg b.wt (G5) & $0,313 \pm 0,114$
\end{tabular}




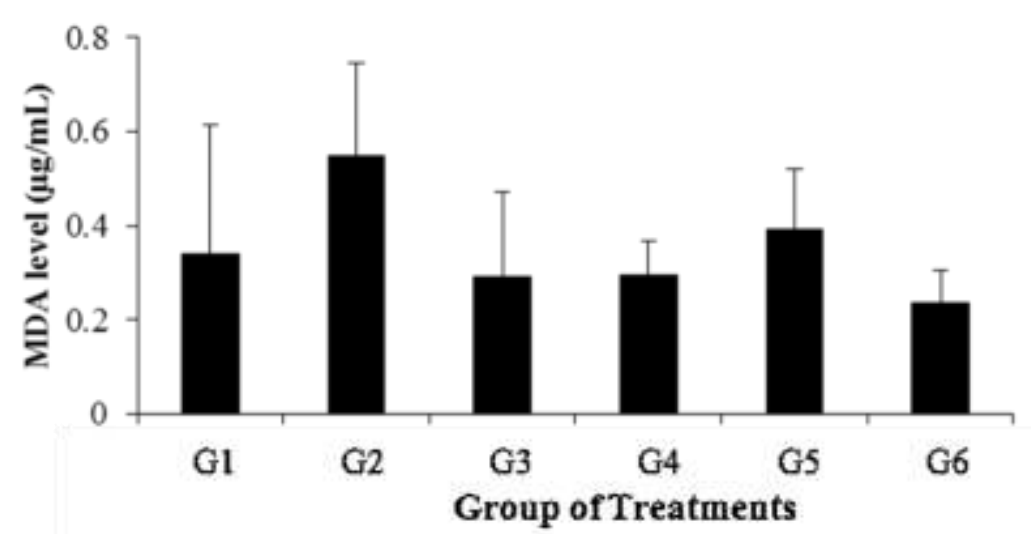

Fig. 3. The level of malondialdehyde (MDA) on rat liver after 45 days of treatments. Values are mean $\pm \mathrm{SD}(\mathrm{n}=5)$. G1, control rats; G2, cigarette-smoke exposed rats; G3, cigarette smoke+Vit. C; G4, cigarette smoke+CZE $350 \mathrm{mg} / \mathrm{kg}$ b.wt; G5, cigarette smoke+CZE $525 \mathrm{mg} / \mathrm{kg}$ b.wt; G6, CZE $525 \mathrm{mg} / \mathrm{kg}$ b.wt.

Measurement of Malondialdehyde (MDA) levels as an indicator of lipid peroxidation carried out by thiobarbituric acid (TBA) method describes in Table 3. The mean MDA level of the negative control group was higher $37.97 \%$ than the normal group, and $46.53 \%$ higher than the positive control group receiving Vit.C. The higher level of MDA shows that exposures to cigarette smoke for 45 days was able to increase levels of free radicals in the body. This result is in line with the statement that cigarette smoke contains components that increase levels of free radicals in the body, thus potentially caused damage to liver cells [32],[33].

Meanwhile, the treatment groups receiving cigarette smoke and coadministered by Vit.C or CZE subsequently showed lower levels of liver's MDA compare to negative control and normal groups. The average level of MDA in G4 (CZE $350 \mathrm{mg} / \mathrm{kg} \mathrm{b} . \mathrm{wt}$ ) is almost the same as the average MDA level of G3-the positive control group given vitamin $\mathrm{C}$ as a standard antioxidant meaning that orally administered of CZE has a reducing effect to MDA levels in rat liver. Moreover, the group which only received CZE $525 \mathrm{mg} / \mathrm{kg}$ b.wt had an average MDA level lower than all other treatment groups as well as showed no different statistically on AST, ALT, ALP levels to the normal control group (G1). This finding was in accordance by other studies which identified that the ethanol extract of some turmeric plants had free radical scavenger's activity to protect damage on hepatocytes but relatively has no toxic effect to liver cells [16][13]. The hepatoprotective effect of Curcuma zedoaria was supported by the antioxidant activity of curcumin and other essential oils as the active compounds which contain monoterpenes and sesquiterpenes (furanogermone) [34].

\subsection{Conclusion}

Administration of Curcuma zedoaria (Berg.) Roscoe Extract $350 \mathrm{mg} / \mathrm{kg}$ b.wt., and 525 $\mathrm{mg} / \mathrm{kg}$ b.wt. Reduced total protein, ALT, AST, and ALP levels as well as decreased liver peroxidase level based on the average profile of MDA on rats exposed by cigarette smoke. Therefore, it can be concluded that the administration of Curcuma zedoaria (Berg.) Roscoe 
Extract $350 \mathrm{mg} / \mathrm{kg}$ b.wt., and $525 \mathrm{mg} / \mathrm{kg}$ b.wt. showed the hepatoprotective effect on rats exposed by cigarette smoke.

Acknowledgments. This research is a part of studies on assessing the antioxidant properties of Curcuma zedoaria supported by Benua Maritim Indonesia Spesifik (BMIS) research scheme of Hasanuddin University. Therefore, authors gratefully acknowledge access to research facilities at the Fakultas Farmasi as well as thankful to Universitas Hasanuddin, Makassar for its financial support.

\section{References}

[1] WHO,.: "WHO global report on trends in the prevalence of tobacco smoking 2000-2025 (2018)

[2] H. R. Eriksen, M., J. Mackay., The Tobacco Atlas, 4th ed. Atlanta: American Cancer Society (2012)

[3] H. Van Der Vaart, D. S. Postma, W. Timens, and N. H. T. Ten Hacken.:, "Acute effects of cigarette smoke on inflammation and oxidative stress: A review," Thorax, vol. 59, no. 8, pp. 713$721,(2004)$

[4] D. K. Semwal, S. P. Mishra, A. Chauhan, and R. B. Semwal.: Adverse Health Effects of Tobacco and Role of Ayurveda in their Reduction," J. Med. Sci., vol. 15, no. 3, pp. 139-146 (2015)

[5] Z. Chen.: Oxidative DNA damage is involved in cigarette smoke-induced lung injury in rats," Environ. Health Prev. Med., vol. 20, no. 5, pp. 318-324 (2015)

[6] K. C. Kregel and H. J. Zhang.: An integrated view of oxidative stress in aging: basic mechanisms, functional effects, and pathological considerations," AJP Regul. Integr. Comp. Physiol., vol. 292, no. 1, pp. R18-R36 (2006)

[7] W. Dröge.: Free Radicals in the Physiological Control of Cell Function," Physiol. Rev., vol. 82, no. 1, pp. 47-95 (2002)

[8] M. Valko, D. Leibfritz, J. Moncol, M. T. D. Cronin, M. Mazur, and J. Telser,.:Free radicals and antioxidants in normal physiological functions and human disease," Int. J. Biochem. Cell Biol., vol. 39, no. 1, pp. 44-84 (2007)

[9] R. Jayaprakash, V. Ramesh, M. P. Sridhar, and C. Sasikala, .:Antioxidant activity of ethanolic extract of Tinospora cordifolia on N-nitrosodiethylamine (diethylnitrosamine) induced liver cancer in male Wister albino rats.," J. Pharm. Bioallied Sci., vol. 7, no. Suppl 1, pp. S40-5, Apr. 2015.

[10] C. D. Scripture and W. D. Figg.: Drug interactions in cancer therapy," Nat. Rev. Cancer, vol. 6, p. 546, (2006)

[11] S. Sumarheni .:Human full-length coagulation factor $\mathrm{x}$ and a GLA domain-derived 40-mer polypeptide bind to different regions of the adenovirus serotype 5 hexon capsomer," Hum. Gene Ther., vol. 25 (2014)

[12] H. E. Seifried, D. E. Anderson, E. I. Fisher, and J. A. Milner, "A review of the interaction among dietary antioxidants and reactive oxygen species," J. Nutr. Biochem., vol. 18, no. 9, pp. 567-579 (2007)

[13] V. Kumar, P. C. Bhatt, M. Rahman, F. A. Al-Abbasi, F. Anwar, and A. Verma, "Umbelliferon- $\alpha-d-$ glucopyranosyl-(2I $\rightarrow 1 \mathrm{II})-\alpha$-Dglucopyranoside ameliorates Diethylnitrosamine induced precancerous lesion development in liver via regulation of inflammation, hyperproliferation and antioxidant at pre-clinical stage," Biomed. Pharmacother., vol. 94, pp. 834-842 (2017)

[14] N. Vi, M. Agapietta, K. Laelatul, R. Novi, and H. Kurniati, "The Effects of Turmeric Extract ( Curcuma domest ; ca Val ) on Cigarette Smoke Cardiotoxicity in The Wistar Rats," J. Sain Vet., vol. 31, no. 2, pp. 89-99 (2013)

[15] N.-H. Loc, D.-T.-H. Diem, D.-H.-N. Binh, D.-T. Huong, T.-G. Kim, and M.-S. Yang, "Isolation and Characterization of Antioxidation Enzymes from Cells of Zedoary (Curcuma zedoaria Roscoe) Cultured in a 5-1 Bioreactor," Mol. Biotechnol., vol. 38, no. 1, pp. 81-87 (2008)

[16] A. Saetung, A. Itharat, C. Dechsukum, C. Wattanapiromsakul, N. Eawpradub, and P. Ratanasuwan, "Cytotoxic activity of Thai medicinal plants for cancer treatment," Songklanakarin J Sci ..., vol. 
27, no. Suppl. 2, pp. 469-478 (2005)

[17] Departemen Kesehatan RI, Farmakope Herbal Indonesia, Edisi I. Jakarta (2008)

[18] S. A. K. Retno Murwanti, Edy Meiyanto, Arief Nurrochmad, "Effect of Curcuma zedoaria Rosc. ethanolic extract on the lung tumor growth on post initiation phase in female mice induced by Benzo(a)pyrene," Maj. Farm. Indones., vol. 15, no. 1, pp. 7-12 (2004)

[19] H. Ohkawa, N. Ohishi, and K. Yagi, "Assay for lipid peroxides in animal tissues by thiobarbituric acid reaction," Anal. Biochem., vol. 95, no. 2, pp. 351-358 (1979)

[20] C. Ji, C. Li, W. Gong, H. Niu, and W. Huang, "Hypolipidemic Action of hydroxycinnamic Acids from Cabbage (Brassica oleracea L. var. capitata) on Hypercholesterolaemic Rat in Relation to Its Antioxidant Activity," J. Food Nutr. Res., vol. 3, no. 5, pp. 317-324 (2015)

[21] K. R. Pritchett and B. F. Corning, "Biology and Medicine of Rats. In: Laboratory Animal Medicine and Management," International Veterinary Information Service (www.ivis.org) (2004)

[22] H. Chen, R. Vlahos, S. Bozinovski, J. Jones, G. P. Anderson, and M. J. Morris, "Effect of ShortTerm Cigarette Smoke Exposure on Body Weight , Appetite and Brain Neuropeptide Y in Mice," pp. 713-719 (2005)

[23] N. E. Grunberg, D. J. Bowen, and D. E. Morse, "Effects of nicotine on body weight and food consumption in rats," Psychopharmacology (Berl)., vol. 83, no. 1, pp. 93-98, (1984)

[24] A. Chiolero, D. Faeh, F. Paccaud, and J. Cornuz, "Consequences of smoking for body weight, body fat distribution, and insulin resistance," Am. J. Clin. Nutr., vol. 87, no. 4, pp. 801-809, Apr. 2008.

[25] L. Ponzoni et al., "Different physiological and behavioural effects of e-cigarette vapour and cigarette smoke in mice," Eur. Neuropsychopharmacol., vol. 25, no. 10, pp. 1775-1786 (2015)

[26] M. Wrzesniak, M. Kepinska, M. Królik, and H. Milnerowicz, "The influence of Tobacco smoke on protein and metal levels in the serum of women during pregnancy," PLoS One, vol. 11, no. 8, pp. $1-16,(2016)$

[27] S. Abdul-Razaq and B. Ahmed, "Effect of cigarette smoking on liver function test and some other related parameters," Zanco J. Med. Sci., vol. 17, no. 3, pp. 556-562 (2013)

[28] E. O. Farombi and O. O. Onyema, "Monosodium glutamate-induced oxidative damage and genotoxicity in the rat: modulatory role of vitamin C, vitamin E and quercetin," Hum. Exp. Toxicol., vol. 25, no. 5, pp. 251-259 (2006)

[29] S. M. Nabavi, S. F. Nabavi, S. Eslami, and A. H. Moghaddam, "In vivo protective effects of quercetin against sodium fluoride-induced oxidative stress in the hepatic tissue," Food Chem., vol. 132, no. 2, pp. 931-935 (2012)

[30] J. L. Kee, Pedoman Pemeriksaan Laboratorium \& Diagnostik, 6th ed. EGC (2008)

[31] R. Ahmadi and S. Eshghjoo, "The Effect Of Cigarette And Waterpipe Smoke On Serum Level Of Alanine Aminotransferase And Aspartate Aminotransferase In Male Rats," J. Payavard Salamat, vol. 8, no. 2, pp. 169-175 (2014)

[32] N. A. A. Mansour, Aulani'am, and J. Kusnadi, "Garciniamangostana Linn . Pericarp Extract Reduced Malondialdehyde ( MDA ) Level in Cigarette Smoke Exposed Rats,” vol. 2, no. 9, pp. 1$5,(2013)$

[33] A. Wijayanti, "Pengaruh pemberian ekstrak kulit buah manggis (Garcinia mangostana) terhadap gambaran histologik hati dan ginjal mencit (Mus musculus) yang terpapar asap rokok," J. Biol., vol. 5, pp. 10-18 (2016)

[34] M. E. M. Braga, P. F. Leal, J. E. Carvalho, and M. A. A. Meireles, "Comparison of Yield, Composition, and Antioxidant Activity of Turmeric ( Curcuma longa L.) Extracts Obtained Using Various Techniques,” J. Agric. Food Chem., vol. 51, no. 22, pp. 6604-6611 (2003) 